\title{
The Asian Green Mussel Perna viridis (Linnaeus 1758): 20 Years after Its Introduction in Trinidad and Tobago
}

\author{
Judith Gobin $^{1 *}$, John Agard ${ }^{1}$, Janette Madera², Azad Mohammed ${ }^{1}$ \\ ${ }^{1}$ Department of Life Sciences, University of the West Indies, St Augustine, Trinidad and Tobago \\ ${ }^{2}$ Laboratories of Analytical Biology, Smithsonian Institution, Suitland, USA \\ Email: *Judith.gobin@sta.uwi.edu
}

Received October 23, 2012; revised March 6, 2013; accepted March 21, 2013

Copyright (C) 2013 Judith Gobin et al. This is an open access article distributed under the Creative Commons Attribution License, which permits unrestricted use, distribution, and reproduction in any medium, provided the original work is properly cited.

\begin{abstract}
Invasive species are often characterised by the introduction of low numbers of individuals and a small genetic pool which could give rise to a population with a lower genetic diversity than the original population. Perna viridis was first reported on the west coast of Trinidad in 1990 in the Point Lisas Industrial estate. They may have been first introduced either as juvenile free floating mussels (spat) or as adults attached to the hulls of ships. This gregarious species spread rapidly throughout the Caribbean to Venezuela, Kingston Harbor (Jamaica) and by 1999 was reported in Tampa Bay (Florida). Genetic analysis was done on tissue samples from Trinidad to determine the genetic similarity of newly collected specimens (2009) with archived specimens (collected 1994). Results suggest that there may not be any genetic variation in the population of Perna viridis, even approximately 20 years after initial colonization. These results suggest that there was no evidence of genetic bottlenecks in the population of $P$. viridis from Trinidad.
\end{abstract}

Keywords: Perna viridis; Green Mussels; Trinidad and Tobago; Invasive Species

\section{Introduction}

The green mussel, Perna viridis (Linnaeus, 1758) is native to the tropical waters of the Indo-Pacific region of Asia [1]. It is a dioecious species that reaches sexual maturity within 2 - 3 months and can live for about 3 years. Perna viridis thrives in coastal waters $(<10 \mathrm{~m})$, in salinities between 16 and $33 \mathrm{ppt}$, at temperatures between $10^{\circ} \mathrm{C}$ and $35^{\circ} \mathrm{C}$ (optimal: 27 to $33 \mathrm{ppt}, 26^{\circ} \mathrm{C}$ to $32^{\circ} \mathrm{C}$ ), and exhibit a wide tolerance range for turbidity and pollution $[2,3]$. They are often found attached to hard structures in the midlittoral and sublittoral areas in densities of up to 35,200 individuals $/ \mathrm{m}^{2}$ [4]. Perna viridis is characterised by its fast growth and relatively high tolerance to environmental variables such as temperature, salinity and pollution [5-7]. Their well-developed byssal apparatus allows them to form dense clusters which effectively modify the natural ecosystem and out-compete other organisms (Figure 1).

P. viridis was first reported at Point Lisas on the west coast of Trinidad in 1990 [8]. This was also the first record of the species in the Atlantic region. It was thought to have arrived in Trinidad from the Indo-Pacific region either as "spat" in ballast water or as adults attached to

${ }^{*}$ Corresponding author. the hulls of ships [8]. Throughout the 1990s, P. viridis continued to colonize west coast locations, in particular, the major ports and areas of high shipping activity (Figure 2). This gregarious species spread rapidly throughout

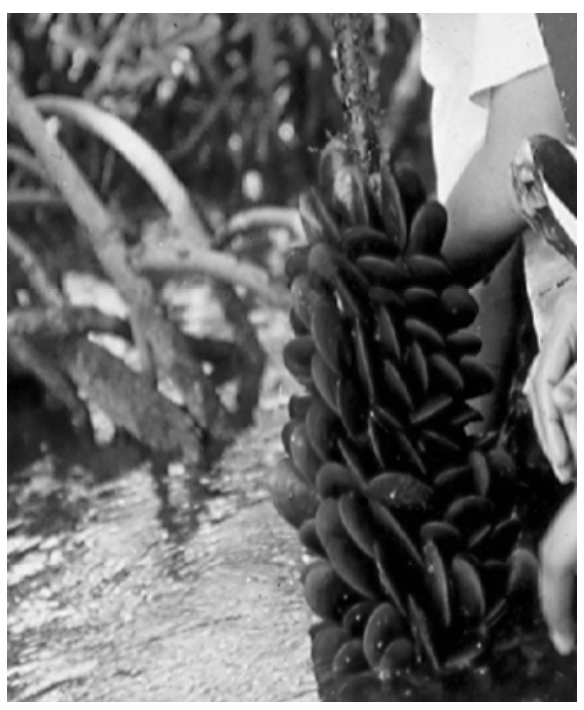

Figure 1. Colonization of mangrove (Rhizophora mangle) roots by Perna viridis in Caroni swamp, Trinidad (1992) (Photo by John Agard). 
the Caribbean and populations were subsequently reported in Venezuela in 1993 [9], in Kingston Harbor, Jamaica in 1998 [10] and in Tampa Bay, Florida in 1999 [4,11-13] (Figure 3). Initial colonization by $P$. viridis was thought to have occurred with the introduction of a small number of individuals. The initial introduction of low numbers and small pool of genetic material could have given rise to a population bottleneck which may have resulted in a new population with a lower genetic diversity, when compared to the original population. A number of conflicting views about the role of genetic bottlenecks in invasion biology have been presented. Traditionally, genetic bottlenecks were thought to decrease the potential for adaptive evolution because of a reduce-

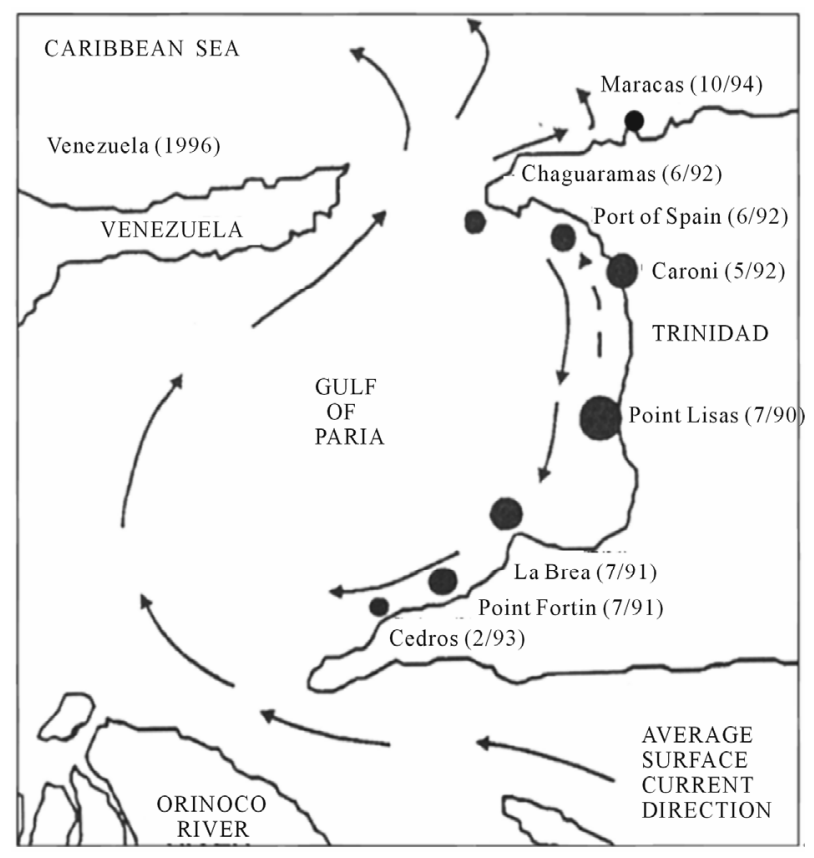

Figure 2. Chronology of colonization of Perna viridis in the Trinidad (Adapted from Agard et al., 1990 [8]).

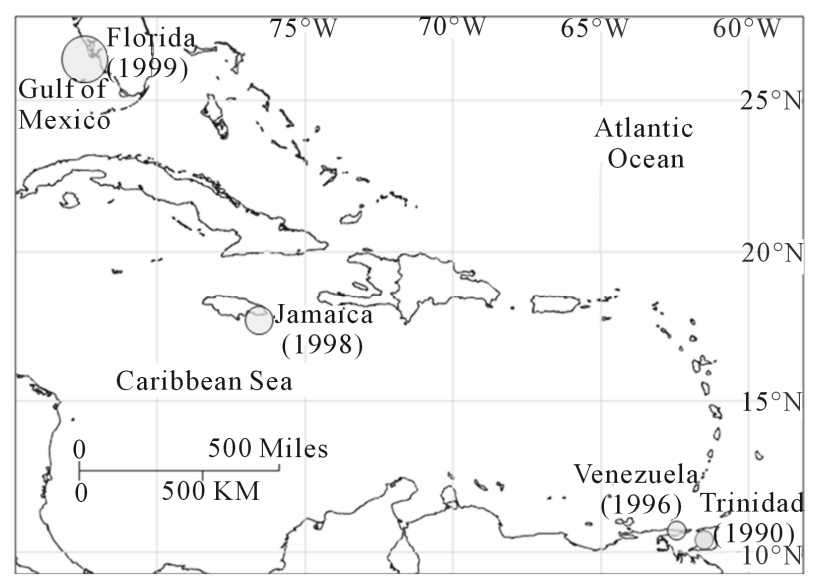

Figure 3. Chronology of colonization of Perna viridis in the Caribbean. tion in the quantitative variation within a population. However, recent theories suggested that bottlenecks may lead to increase genetic variance in founding populations because of the conversion of epistatic to additive variance, and hence could promote rapid adaptive evolution $[14,15]$.

Invasive species also frequently experience founding effects that reduce their genetic variability (and may account for the loss of genetic variation), as the new population becomes reproductively separated from the main population. This reduced genetic variability may be as a result of significant inbreeding which lowers their ability to evolve, and would inevitably reduce their persistence in the new environment [16]. Additionally, as a result of the loss of genetic variation, the new population may be distinctively different, both genetically and phenotypically, from the parent population. In extreme cases, the founder effect may explain speciation and subsequent evolution of a new species. Kolbe et al. (2004) [17] showed that the blending of genetic material from different geographical sources across an invasive species native range resulted in an invasive population of Anolis sagrei that was genetically different from the native population.

Twenty years after its initial introduction into Trinidad, the distribution of $P$. viridis can now be described as patchy, with isolated populations along the west coast. Baker et al. (2007) [18] similarly described green mussel populations as patchy, in the coastal waters of northeast Florida. In this study, we confirm the identity of $P$. viridis in Trinidad and examine the genetic similarity of newly collected specimens (2009) with archived specimens collected in 1994 to determine whether there have been any genetic variations post-colonization.

\section{Method}

Samples of $P$. viridis were collected in February 2009, at four sites (Cedros, Point Lisas, San Fernando and Chaguaramas) where its presence was previously [9]. Genetic analysis of tissue samples were done at the Laboratories of Analytical Biology, Smithsonian Institution. Tissue samples were digested with $150 \mu \mathrm{L}$ of Autogen M2 buffer and $150 \mu \mathrm{L}$ of Autogen M1 buffer with Proteinase $\mathrm{K}$ at $56^{\circ} \mathrm{C}$ in a shaker incubator. DNA extraction was performed using the Autogen Prep 956 Extractor. The DNA was eluted in $50 \mathrm{uL}$ of Autogen R9 buffer. CO1 amplification was carried out with primers: M13(F)-29-dgLCO1490 and M13(R)-dgACO2198, each at $10 \mathrm{mM}$ concentrate, with $1 \mu \mathrm{L}$ DNA extracts in $10 \mu \mathrm{L}$ reactions. The annealing temperature in the amplification was $48^{\circ} \mathrm{C}$ with 36 cycles. PCR runs were done on $1.5 \%$ SeaKem LE agarose gels and 1.2\% - 1.3\% NuSieve GTG agarose gels. The amplified samples were cleaned up 
using gel purification and run on a thermal cycler: 10 minutes at $72^{\circ} \mathrm{C}$ and $2-3$ minutes at $45^{\circ} \mathrm{C}$ before adding $1 \mu \mathrm{L}$ of gelase to each amplified sample and incubated for a few hours at $45^{\circ} \mathrm{C}$ prior to sequencing. The resulting sequences were mapped onto a $\mathrm{NJ}$ tree for analysis using the software Paup. A distance analysis with a Neighborjoining search was performed.

Genetic results from these samples are compared with reference GenBank samples for various species of Perna (Table 1) as well as the archived samples from Trinidad which had been collected in 1994.

\section{Results and Discussion}

Phylogenetic comparison between species collected from Trinidad in 2009 confirmed their identity as Perna viridis, based on comparison with GenBank references for Perna species. Comparison of the intraspecific distance with Perna perna (0.208), Perna indica (0.22), and Perna canaliculus (0.252) showed that these were distinctly phylogenetically different from Perna viridis. Perna viridis (Trinidad) had an average intraspecific distance of $0.002(0.000-0.009)$. Trinidad samples gave an intraspecific distance ranging between 0.005 and 0.008 , when compared to the GenBank Perna viridis sample. Similarly the archived Trinidad samples from 1994 gave an intraspecific distance of 0.005 , which suggests that there may not be any genetic variation in the population of Perna viridis, even 20 years after initial colonization.

Benson et al. (2001) [11] also confirmed that the green mussels in Florida were $P$. viridis, and were closely related to $P$. viridis from Trinidad. These results suggest that there was no evidence of genetic bottlenecks in the population of $P$. viridis from Trinidad. Kolbe et al. (2004) [17] suggested that the lack of genetic variation in an invasive species decreases its chances of establishment during introduction, which could account for the lower than predicted success of $P$. viridis colonization in Trinidad. This can also be explained by the "Wahlund effect" which occurs when genetically similar family clusters are created, as frequently happens with invasive

Table 1. GenBank samples used for NJ tree.

\begin{tabular}{cc}
\hline Species & Accession number \\
\hline Perna canaliculus & DQ343603 \\
Perna indica & FJ428754 \\
Perna perna & DQ351451 \\
Perna perna & DQ351432 \\
Perna viridis & FJ428757 \\
Perna viridis & DQ343582 \\
Perna viridis & DQ343573 \\
\hline
\end{tabular}

species, leading to a reduction of heterozygosity. The underlying cause of this could be the geographic barrier to gene flow from the original population. However, secondary introductions from other colonized areas in the Caribbean may greatly favor the persistence of the species in the region resulting in little loss of genetic diversity.

These results support electrophoretic analysis of allozymes done on specimens in 1992, by the Plymouth Marine Laboratory. Coding for enzymes confirmed the identification of the new arrivals as Perna viridis [8]. Interestingly the elecrophoretic results also showed that the LAP enzyme which was previously reported in greenlipped mussels ( $P$. viridis) from the West Coast of Peninsular Malaysia [19] was not present in any of the specimens analysed from Trinidad (B. bayne pers. comm.). This result is unlike any other reported for $P$. viridis and warrants further investigation.

\section{REFERENCES}

[1] S. E. Siddall, "A Classification of the Genus Perna," Bulletin of Marine Science, Vol. 30, No. 4, 1980, pp. 858870.

[2] P. M. Sivalingam, "Aquaculture of the Green Mussel Mytilus viridis Linnaeus, in Malaysia," Aquaculture, Vol. 11, No. 4, 1977, pp. 297-312. doi:10.1016/0044-8486(77)90079-5

[3] S. Y. Lee, "Growth and Reproduction of the Green Mussel, Perna viridis Linnaeus, (Bivalvia:Mytilacea) in Contrasting Environments in Hong Kong," Asian Marine Biology, Vol. 3, 1986, pp. 111-127.

[4] S. Y. Lee, "The Population Dynamics of the Green Mussel, Perna viridis Linnaeus, in Victoria Harbour, Hong Kong-Dominance in a Polluted Environment," Asian Marine Biology, Vol. 2, 1985, pp. 107-118.

[5] S. Rajagopal, G. Van der Velde, M. Van der Gaag and H. A. Jenner, "How Effective Is Intermittent Chlorination to Control Adult Mussel Fouling in Cooling Water Systems?" Water Research, Vol. 37, No. 2, 2003, pp. 329 -338. doi:10.1016/S0043-1354(02)00270-1

[6] S. Rajagopal, G. Van der Velde, M. Van der Gaag and H. A. Jenner, "The Greening of the Coast: A Review of the Perna viridis Success Story," Aquatic Ecology, Vol. 40, No. 3, 2006, pp. 273-297. doi:10.1007/s10452-006-9032-8

[7] K. S. Sundaram and M. S. Shafee, "Salinity Tolerance of Some Bivalves of Ennore Estuary," Journal of the Marine Biological Association of India, Vol. 31, 1989, pp. 299302.

[8] J. Agard, R. Kishore and B. Bayne, "Perna viridis (Linnaeus 1758): First Record of the Indo-Pacific Green Mussel (Mollusca:Bivalvia) in the Caribbean," Caribbean Marine Studies, Vol. 3, 1992, pp. 59-60.

[9] K. Rylander, J. Perez and J. Gomez, "The Distribution of the Brown Mussel, Perna perna and the Green Mussel $P$. viridis (Mollusca:Bivalvia:Mytilidae) in North Eastern 
Venezuela," Caribbean Marine Studies, Vol. 5, 1996, pp. 86-87.

[10] D. S. A. Buddo, R. D. Steele and E. R. D'Oyen, “Distributions of the Invasive Indo-Pacific Green Mussel, Perna viridis, in Kingston Harbour, Jamaica," Bulletin of Marine Science, Vol. 73, No. 2, 2003, pp. 433-441.

[11] A. J. Benson, D. C. Marelli, M. E. Frischer, J. M. Danforth and J. D. Williams, "Establishment of the Green Mussel, Perna viridis (Linnaeus 1758) (Mollusca: Mytilidae) on the West Coast of Florida," Journal of Shellfish Research, Vol. 20, 2001, pp. 19-21.

[12] D. A. Ingrao, P. M. Mikkelsen and D. W. Hicks, "Another Introduced Marine Mussel in the Gulf of Mexico: the Indo-Pacific Green Mussel, Perna viridis (Linnaeus 1758) in Tampa Bay, Florida," Journal of Shellfish Research, Vol. 20, 2001, pp. 13-19.

[13] A. J. Power, R. L. Walker, K. Payne and D. Hurley, "First Occurrence of the Non-indigenous Green Mussel, Perna viridis in Coastal Georgia, United States," Journal of Shellfish Research, Vol. 23, 2004, pp. 741-744.

[14] Y. Naciri-Graven and J. Goudet, "The Additive Genetic Variance after Bottlenecks Is Affected by the Number of Loci Involved in Epistatic Interactions," Evolution, Vol. 57, No. 4, 2003, pp. 706-716. doi:10.1111/j.0014-3820.2003.tb00284.x
[15] J. Van Buskirk and Y. Willi, "The Change in Quantitative Genetic Variation with Inbreeding," Evolution, Vol. 60, No. 12, 2006, pp. 2428-2434. doi:10.1554/06-485.1

[16] F. W. Allendorf and L. L Lundquist, "Introduction: Population Biology, Evolution, and Control of Invasive Species," Conservation Biology, Vol. 17, No. 1, 2003, pp. 24 30. doi:10.1046/j.1523-1739.2003.02365.x

[17] J. J. Kolbe, R. E. Glor, L. R. Schettino, A. C. Lara, A. Larson and J. B. Losos, "Genetic Variation Increases During Biological Invasion by a Cuban Lizard," Nature, Vol. 431, No. 7005, 2004, pp. 177-181. doi: $10.1038 /$ nature 02807

[18] P. Baker, J. S. Fajans, W. S. Arnold, D. A. Ingrao, D. C. Marelli and S. M. Baker, "Range and Dispersal of a Tropical Marine Invader, the Asian Green Mussel, Perna viridis in Subtropical Waters of the Southeastern United States," Journal of Shellfish Research, Vol. 26, No. 2, 2007, pp. 345-355. doi:10.2983/0730-8000(2007)26[345:RADOAT]2.0.CO; 2

[19] C. K. Yap, S. G. Tan, A. Ismail and H. Omar, "Genetic Variation of the Green-Lipped Mussel Perna viridis Linnaeus, (Mytilidae:Mytiloida:Mytilicae) from the West Coast of Peninsular Malaysia," Zoological Studies, Vol. 41, No. 4, 2002, pp. 376-387. 